СТРУКТУРНО-ФУНКЦІОНАЛЬНА МОДЕЛЬ

СОЦІАЛЬНО-ЕКОНОМІЧНОЇ ПІДГОТОВКИ КУРСАНТІВ І СЛУХАЧІВ У ПРОЦЕСІ БЕЗПЕРЕРВНОЇ ОСВІТИ В НАЦІОНАЛЬНІЙ АКАДЕМІЇ ДЕРЖАВНОЇ ПРИКОРДОННОЇ СЛУЖБИ УКРАЇНИ

\title{
STRUCTURAL-FUNCTIONAL MODEL OF SOCIO-ECONOMIC TRAINING OF CADETS AND STUDENTS IN THE PROCESS OF CONTINUOUS EDUCATION IN THE NATIONAL ACADEMY OF THE STATE BORDER GUARD SERVICE OF UKRAINE
}

УДК 378

DOI https://doi.org/10.32843/2663-60852019-18-1-30

\section{Дияк В.В.,}

канд. пед. наук,

доцент кафедри педагогіки

та соціально-економічних дисциплін

Національної академії

Державної прикордонної служби

України імені Богдана Хмельницького у статmі здійснено спробу відтворити структуру й описати змістове наповнення структурно-фуункціональної моделі соціально-економічної підготовки курсантів і слухачів у прочесі безперервної освіти в Національній академії Державної прикордонної служби України (НАДПСУ). Дослідження педагогічних явищ на теоретичному рівні пов'язане з розробкою моделей, які дозволяють вивчати об'єкт локально, з подальшим перенесенням результатів у широкий освітній простір. Враховувалося, що під час побудови структурно-фрункціональних моделей об'єкт розглядається як цілісна система, яку розчленовують на складові частини, компоненти, елементи, підсистеми. Структурні складники системи поєднані між собою певними взаємозалежними фуннкціональними зв'язками, що візуалізуються у вигляді різних схем, відтворюють підпорядкованість, логічну і тимчасову послідовність вирішення окремих дослідницьких завдань.

Запропонована структурно-функкціональна модель $\epsilon$ проекцією концептуальних положень наукової розвідки на сферу педагогічної практики соціально-економічної підготовки курсантів і слухачів у процесі навчання в НАДПСУ. Схематичне зображення структурнофуункціональної моделі дозволяє відтворити змістові та структурні взаємозв'язки і взаємозалежності всіх блоків для досягнення очікуваного результату: сфрормованої соиіально-економічної компетентності здобувачів освіти в Національній академії Державної прикордонної служби України. Моделювання складних об'єктів, яким розглянуто соціально-економічну підготовку курсантів і слухачів упроцесі безперервної освіти у НАДПСу, супроводжується деталізацією локальних схем, які розкривають зміст окремих організаційно-змістових блоків, що є підсистемами в чілісній системі. Розроблена концепту альна структурно-срункціональна модель соціально-економічної підготовки курсантів і слухачів у процесі безперервної освіти у НАДПСУ містить сукупність взаємопов'язаних блоків: чільового, теоретико-методологічного, змістовно-практичного, оціночно-аналітичного, результативного.

Ключові слова: модель, моделювання, безперервна освіта, курсанти, слухачі, структурно-фрункціональна модель.
The article deals with an attempt to reproduce the structure and describe the semantic content of the structural-functional model of socioeconomic training of cadets and students in the process of continuous education in the National Academy of the State Border Guard Service of Ukraine (NASBGSU). It has been generalized that the research of pedagogical phenomena at the theoretical level is related to the development of models, which allow studying object locally, with the subsequent transfer of the results to a wide educational space. It has been taken into account that during the construction of structural-functional models, the object is seen as a complete system, which is dismembered into its constituent parts, components, elements, subsystems. Structural components of the system are interconnected by certain interrelated functional connections that are visualized in the form of different schemes, reproduce the subordination, logical and temporal sequence of the solution of individual research tasks.

The proposed structural-functional model is a projection of conceptual provisions of scientific exploration in the field of pedagogical practice of socio-economic training of cadets and students in the process of studying in the NASBGSU. The schematic illustration of structural-functional model allows reproducing meaningful and structural interconnections and interdependencies of all blocks for achieving the expected result: formed socio-economic competence of education recipients in the National Academy of the State Border Guard Service of Ukraine. Modeling of complex objects, which is considered socioeconomic training of cadets and students in the process of continuous education in the NASBGSU, is accompanied by detailing local schemes that reveal the content of individual organizational and content blocks, which are subsystems in a coherent system. The developed conceptual structural-functional model of socio-economic training of cadets and students in the process of continuous education in the NASBGSU includes a set of interconnected blocks: target, theoreticalmethodological, content-practical, evaluativeanalytical, resultative.

Key words: model, modeling, continuous education, cadets, students, structural-functional model.
Постановка проблеми у загальному вигляді. Наукове обґрунтування педагогічних явищ на теоретичному рівні пов'язане з розробкою моделей, що дозволяють вивчати досліджувані об'єкти (наприклад, певні аспекти профресійної підготовки в загальній системі вищої освіти) локально, 3 подальшим перенесенням результатів у широкий освітній простір. Соціально-економічна підготовка (СЕП) курсантів і слухачів у процесі безперервної освіти в НАДСПУ є цілісною системою, специфіку якої можна розглядати на методологічному, теоретичному і практичному рівнях. Таке уявлення дозволяє визначити ії характерні ознаки в системному, процесуальному та діяльнісному аспектах. 
Системний аспект СЕП репрезентований у науковому обґрунтуванні взаємопов'язаних вимог до соціально-економічної підготовленості персоналу Державної прикордонної служби України. Процесуальний аспект дозволяє уявити взаємозв'язок і взаємовплив усіх складників досліджуваної системи СЕП курсантів і слухачів НАДПСУ. Діяльнісний (практичний) аспект формування соціальноекономічної компетентності курсантів і слухачів у НАДПСУ в процесі безперервної освіти в розробленій моделі пов'язаний із реалізацією виокремлених організаційно-педагогічних умов на практиці. Основні положення методу педагогічного моделювання використані для побудови уніфікованої структурно-фрункціональної моделі соціально-економічної підготовки курсантів і слухачів у процесі безперервної освіти в НАДСПУ.

У сучасній науці під моделлю розуміється аналог (схема, структура, знакова система) певного фррагмента природної або соціальної реальності, наприклад, освіти, що розглядається як оригінал моделі [2]. У більш розгорнутому трактуванні процес моделювання визначається вченими як «науковий метод дослідження різних систем шляхом побудови моделей цих систем, які зберігають деякі основні особливості предмета дослідження і передбачають вивчення фрункціонування моделей із перенесенням одержуваних даних на предмет дослідження» [8, с. 118]. Таким чином, із гносеологічного погляду модель у педагогічних дослідженнях можна трактувати як схематичне зображення певного процесу - оригіналу, що дає змогу його структурувати, визначити напрями трансорормаційних змін, що сприятиме поглибленому пізнанню досліджуваних процесів і використанню їх на практиці. Таким чином, виступаючи засобом пояснення, передбачення й евристики, модель виконує пізнавальну роль. Однак моделі можуть виступати не тільки як один із засобів відображення явищ і процесів реальності, але і як критерій перевірки наукових знань, який застосовується безпосередньо за допомогою встановлення результативності використання різних ідентичних моделей або за допомогою практично доведених теорій.

Аналіз останніх досліджень і публікацій. Відомо, що не всі процеси піддаються кількісному вимірюванню і контролю. Соціальні, культурні, гуманітарні процеси відрізняються винятковою складністю, в них взаємодіють чинники, вплив яких $€$ варіативним, а інтенсивність і характер мінливими і непередбачуваними. Тому дослідники (О. Маслій, І. Мельничук, Н. Мороз, А. Мота, С. Мул, М. Науменко, Н. Ничкало, Т. Новікова та ін.) вбачають за необхідне оперувати якісними судженнями, вирішуючи слабоструктуровані, несормалізовані соціокультурні проблеми. Така діяльність, за словами сучасних науковців (О. Падалка, С. Сисоєва, О. Пометун, В. Собко, Є. Суїменко та ін.), потребує опори на допоміжні засоби, які полегшують складний концептуальний аналіз, допомагають виявити межі доступних дій і знайти перспективний напрям пошуку рішень. Відтак важливого значення набувають методи аналізу якісного змісту процесів у соціокультурній сорері. Для цього необхідна побудова різних моделей, фрункціями яких $є$ поглиблення пізнання діючих систем, форматування, визначення шляхів подальшого вдосконалення, порівняльний аналіз оригіналу і моделі, виявлення якісних характеристик процесів і явищ.

Виділення не вирішених раніше частин загальної проблеми. Однак резюмування наукових доробків сучасних авторів засвідчило відсутність цілеспрямованих досліджень у напрямі розробки структурно-функціональної моделі соціально-економічної підготовки курсантів і слухачів у процесі безперервної освіти у НАДПСУ.

Мета статті. Основним завданням статті $€$ конкретизація важливих структурних складників анонсованої структурно-фрункціональної моделі соціально-економічної підготовки курсантів і слухачів у процесі безперервної освіти у НАДПСУ.

Виклад основного матеріалу. Нині в наукових колах моделі групуються на дві категорії: змістові та формальні. Класифікаційною характеристикою найчастіше виступає мова, яка використовується для розробки такої моделі. Так, для пояснення змістової моделі застосовується природна мова спілкування, а формальна модель втілюється за допомогою однієї або декількох фрормальних мов (наприклад, мов програмування).

У соціально-культурній, гуманітарній сорерах, до яких належить вища військова освіта, частіше використовуються змістові моделі. Гносеологічна доцільність таких моделей під час вивчення педагогічних, дидактичних, методичних проблем військової профресійної освіти підтверджується численними дисертаційними дослідженнями (А. Білорус [1], О. Блажук [2], І. Блощинський [3], Н. Боярчук [4], О. Діденко [5], Г. Дмитренко [6], Н. Левчук [7], К. Тушко [8] та ін.).

Примітно, що за фрункціональною ознакою змістові моделі поділяються на описові, пояснювальні та прогностичні. Описовою моделлю можна назвати будь-яку презентацію чи опис об'єкта. Пояснювальні моделі мають на меті відповісти на питання, чому відбувається те чи інше явище, процес. Прогностичні моделі покликані відтворити майбутню поведінку об'єкта, тобто відповідати на питання, до яких змін призводить той чи інший вплив на досліджуваний об'єкт. Прогностичні моделі не обов'язково містять пояснювальні моделі. Задовільний прогноз можна отримати і на основі емпіричних узагальнень, використовуючи тільки дані описової моделі.

Концептуальною моделлю називається змістовна модель, для розробки якої використовуються теоретичні концепти та конструкти певної 
предметної галузі знання. У більш широкому сенсі під концептуальною моделлю розуміють змістовну модель, що базується на певній концепції або точці зору. Формулювання концептуальної моделі здебільшого є досягненням певного рівня абстрагування на шляху від попереднього опису об'єкта до його формальної моделі. Концептуальні моделі втілюються або у вербальній фрормі, або у змішаній вербально-візуальній репрезентації. Нині педагоги, в т. ч. військові, виокремлюють три види концептуальних моделей: логіко-семантичні, структурно-фрункціональні та причинно-наслідкові. Детальний аналіз характеристик кожного виду моделей дав змогу припустити, що найефективніше СЕП курсантів і слухачів у процесі безперервної освіти у НАДПСУ відображатиме структурно-фрункціональна модель.

Враховувалося, що під час побудови структурно-функціональних моделей об'єкт розглядається як цілісна система, яку розчленовують на складові частини, компоненти, елементи, підсистеми. Структурні складники системи поєднані між собою певними взаємозалежними функціональними зв'язками, що візуалізуються у вигляді різних схем, відтворюють підпорядкованість, логічну і тимчасову послідовність вирішення окремих дослідницьких завдань. За допомогою таких схем зручно аналізувати роль і призначення окремих підсистем щодо цілого, оцінювати взаємозв'язки і залежності окремих елементів.

Водночас для розробки моделі СЕП курсантів і слухачів у процесі безперервної освіти у НАДПСУ ми керувалися прийнятими в теорії моделювання етапами побудови моделі та брали до уваги інші характеристики моделі, пов'язані з логікою її побудови. Зупинимося на короткій характеристиці згаданих етапів.

У межах дослідження джерелом моделювання виступала реальність, реальний об'єкт - освітній процес у НАДПСУ, складником якого $є$ соціальноекономічна підготовка курсантів і слухачів на різних етапах здобуття вищої освіти. Уявний образ об'єкта позначається як «когнітивна» або «ментальна» модель. Тому на етапі створення когнітивної моделі відбувається деяке спрощення реальності, опис об'єкта набуває лаконічності та компактності.

Далі будувалася змістова модель, що дозволяла отримати нову інорормацію про поведінку і стан об'єкта нашого наукового пошуку. Когнітивна модель підлягає перетворенню, ускладненню ії складових частин і їх взаємозв'язків. Зазначимо, що цикл моделювання в гуманітарних науках на цьому етапі зазвичай закінчується, однак можлива і подальша фрормалізація моделі засобами логіки із залученням знань, накопичених у відповідній предметній галузі. Використання формальних засобів аналізу в процесі конструювання авторської схеми дало змогу вивчити «поведінкову динаміку» моделі, отримати нові, неочевидні результати.

Спираючись на наведені положення моделювання, запропоновану в нашому дослідженні модель характеризуватимемо як змістову концептуальну схему, яка має вигляд описової структурно-орункціональної моделі. Анонсована модель розкриває універсальний характер побудови СЕП курсантів і слухачів у процесі безперервної освітив НАДПСУ з опертям на концептуальні положення дослідження і демонструє логіку руху до результату - сорормованої соціально-економічної компетентності майбутніх офріцерів ДПсУ, котрі отримують підготовку на рівнях бакалаврату та магістратури.

Істотною частиною моделювання була постановка цілей, до досягнення яких спрямовувалася організація освітнього процесу в НАДПСУ, та визначення основних структурних блоків і їх обмежень і взаємозв'язків. Виокремлення обмежень передбачало визначення переліку можливих дій, допустимих і неприпустимих станів досліджуваного об'єкта. Оскільки обмеження можуть перешкоджати досягненню виокремлених цілей, зупинимося на характеристиці тих, які доречні для нашої наукової розвідки.

Об'єктом дослідження визначено профресійну підготовку курсантів і слухачів у вищому навчальному закладі прикордонного відомства. Обмеження, задані в роботі, пов'язані з необхідністю реалізації нормативів, визначених в Освітньо-просресійних програмах підготовки першого (бакалаврського) та другого (магістерського) рівнях Галузі знань - 25 «Воєнні науки, національна безпека, безпека державного кордону», а також 3 організаційним регламентом діяльності експериментальної бази дослідження в НАДСПУ. Крім того, враховувалося предметне обмеження, пов'язане зі специфрікою професійної діяльності майбутніх офріцерів ДПСУ. Вважаємо за потрібне відзначити, що виокремлені обмеження не перешкоджали вирішенню поставлених у дослідженні завдань.

Запропонована модель є проекцією концептуальних положень наукової розвідки на сферу практики СЕП курсантів і слухачів у процесі безперервної освітив НАДПСУ. Схематичне зображення моделі дасть змогу показати змістові та структурні взаємозв'язки та взаємозалежності всіх блоків для досягнення очікуваного результату: сорормованої соціально-економічної компетентності здобувачів. Моделювання складних об'єктів, яким є СЕП курсантів і слухачів у процесі безперервної освіти в НАДПСУ, супроводжується деталізацією локальних схем, які розкривають зміст окремих організаційно-змістових блоків, що $€$ підсистемами в цілісній системі. Розроблена концептуальна структурно-фрункціональна модель містить кілька взаємопов'язаних блоків, реалізованих 
в освітньому процесі НАДПСУ, а саме: цільовий, теоретико-методологічний, змістовно-практичний, оцінювально-аналітичний, результативний. Відтак виникає необхідність здійснити коротку характеристику виокремлених блоків, дотримуючись логіки практичної розробки моделі.

Цільовий блок запропонованої схеми відбиває мету нашої наукової розвідки. Загальною стратегічною метою дослідження визначено побудову системи СЕП курсантів і слухачів у процесі безперервної освіти в НАДПСУ відповідно до обраної в дослідженні розвивальної стратегії, результатом якої має стати досягнення соціально-економічної компетентності, що відповідає рівням бакалаврату та магістратури.

Теоретико-методологічний блок авторської моделі відбиває теоретичні основи підготовки курсантів і слухачів у процесі безперервної освіти в НАДПСУ, що відображено у сорормованому понятійно-термінологічному полі дослідження, нормативно-правовому забезпеченні фрахової підготовки майбутніх офріцерів Державної прикордонної служби України та сучасних напрямах наукових досліджень професійної підготовки майбутніх працівників прикордонної служби. Водночас інтеграційна методологія СЕП курсантів і слухачів у процесі безперервної освіти в НАДПСу орієнтує на застосування сукупності наукових підходів для якнайповнішого врахування особистісних потреб здобувачів освіти, специфріки їхньої професійної сорери 3 метою використання всіх розвивальних ресурсів досліджуваного процесу.

Змістовно-практичний блок розробленої структурно-функціональної моделі відбиває зміст соціально-економічної підготовки курсантів і слухачів у процесі безперервної освіти в НАДПСУ, транслювання якого здійснювалося з опорою на триступеневу систему принципів інтегративно-диференційованого навчання майбутніх і діючих офріцерів ДПСУ: методологічні, дидактичні та методичні принципи.

Оцінювально-аналітичний блок розробленої концептуальної структурно-фрункціональної моделі демонструє отримані статистичні дані в кількісному вимірі, що є матеріалом для їх аналізу. Для забезпечення повноти оцінки в дослідженні застосовувався інтегративно-диференційований контроль, який охоплював різноманітні фрорми контролю. Застосування різних видів контролю дало змогу встановити рівень (високий, достатній, задовільний, низький) сфрормованості соціально-економічної компетентності курсантів і слухачів, що пов'язує змістовно-практичний блок із результативним.

Результативний блок концептуальної структурно-функціональної моделі соціально-економічної підготовки курсантів і слухачів у процесі безперервної освітив НАДПСУ вказує на сорормованість в учасників експериментального дослідження соціально-економічної компетентності.
Висновки. Розроблена концептуальна структурно-фрункціональна модель соціально-економічної підготовки курсантів і слухачів у процесі безперервної освіти у НАДПСУ містить сукупність взаємопов'язаних блоків, реалізованих в освітньо-виховному процесі зазначеного ВВН3, а саме: цільового, теоретико-методологічного, змістовнопрактичного, оцінювально-аналітичного, результативного. Запропонована модель відображає найбільш суттєві елементи системи СЕП курсантів і слухачів у процесі безперервної освіти, передбачає стратегічну мету (формування соціально-економічної компетентності) і чотири основні вектори досягнення окресленої мети, що вказують на головні напрями модернізації / вдосконалення / перетворення освітнього процесу в Національній академії Державної прикордонної служби України.

Перспективи подальших наукових розвідок у цьому напрямі вбачаємо у розробці методичних матеріалів для удосконалення процесу соціальноекономічної підготовки курсантів і слухачів у процесі безперервної освіти в НАДПСУ.

\section{БІБЛІОГРАФІЧНИЙ СПИСОК:}

1. Білорус А.М. Педагогічні умови формування інсрормаційної культури у майбутніх офріцерів-прикордонників : автореф. дис. ... канд. пед. наук : 13.00.04. Хмельницький, 2007. 21 с.

2. Блажук О.А. Підготовка майбутніх офріцерівприкордонників до застосування інфоормаційно-телекомунікаційних технологій у забезпеченні системи зв'язку прикордонних підрозділів : дис. ... канд. пед. наук : 13.00.04. Хмельницький, 2012. 240 с.

3. Блощинський І.Г. Основні завдання науковопедагогічного складу Національної академії Державної прикордонної служби України в контексті кредитно-модульної системи організації навчального процесу. Сучасні технології вищої освіти : матеріали VII Всеукр. наук.-метод. конфр. (Одеса, 3-5 жовт. 2012 р.). Одеса : Вид-во ННІХКТЕ, 2012. С. 137-138.

4. Боярчук Н. Модель формування професійної компетентності майбутніх економістів. Педагогічні науки. Полтава, 2013. Вип. 1. С. 85-95. URL: http:// nbuv.gov.ua/UJRN/pena_2013_1_15.

5. Діденко О.В. Теоретико-методичні засади фрормування здатності до профресійної творчості в майбутніх офріцерів Державної прикордонної служби України : автореф. дис. ... докт. пед. наук : 13.00.04. Луганськ, 2009. 40 с.

6. Дмитренко Г.А. Економічна компетентність в системі післядипломної педагогічної освіти : навчальний посібник. Київ : ЦІППО, 2008. 125 с.

7. Левчук Н.П. Діагностика розвиненості економічної компетентності у майбутніх магістрів управління органів Державної прикордонної служби України. Теорія і методика профресійної освіти. 2017. № 13. C. 222-233. URL: https://ivet-ua.science/images/ Journals_IPTO/TMPO/TMPO_13_2017_3. pdf\#page=1.

8. Мельничук І.М. Теорія і практика професійної підготовки майбутніх соціальних працівників засобами інтерактивних технологій : монограсрія. Тернопіль : Економічна думка, 2010. 326 с.

9. Тушко К.Ю. Педагогічні умови формування економічної компетентності майбутніх офріцерів-прикордонників у процесі фрахової підготовки : дис. ... канд. пед. наук : 13.00.04. Хмельницький, 2009. 320 с. 